\title{
TRACES OF VIOLENCE: GADAMER, HABERMAS, AND THE HATE SPEECH PROBLEM
}

\author{
R. GEORGE WRIGHT*
}

\section{INTRODUCTION}

There are a number of ways to approach the published works of Gadamer and Habermas. One can, for example, attempt a careful exegesis of a particular text. This Article, however, will be of a much more opportunistic character. We will herein scavenge the work of Gadamer and Habermas in hopes of making progress on a problem that, admittedly, neither writer has specifically addressed. In particular, we will seek to make progress on understanding the hate speech problem ${ }^{1}$ at its most legally fundamental levels.

We must justify the choice of the hate speech problem as our focus, as well as the choice of Gadamer and Habermas as sources of potential inspiration. Of course, our chosen approach must be judged ultimately by its fruitfulness, or lack thereof. But a few elements of a preliminary justification can be offered at the outset. Over the past two decades or so, a great deal of passion and intellectual energy has been devoted to one aspect or another of the possibility of regulating

* Professor of Law, Cumberland School of Law, Samford University; currently Visiting Professor of Law at Michigan State University-DCL, East Lansing. For the author's previous foray into hate speech law, see chapter 3 in R. GEORGE WRIGHT, THE FUTURE OF FREE SPEECH LAW 57-93 (1990). The author wishes to thank Professor Jay Mootz.

1. We refer herein to "the hate speech problem" solely for convenience. There is admittedly no consensually recognized, monolithic hate speech problem. In fact, the hate speech problem is multiple, taking on different dimensions in diverse legal and social contexts. We will attempt to make such progress as we can without claiming to address all such contexts. For a sense of some of the commonalities and complexities, see generally RICHARD DELGADO \& Jean Stefancic, Must We Defend Nazis?: HATE SPEech, PORNOGRaPHY, and THE NEW FIRST AMENDMENT (1997); MARI J. MATSUDA ET AL., WORDS THAT WOUND: CRITICAL RaCe Theory, Assaultive SPEECH, AND tHe FIRST AMENDMENT (1993); THE PRICE WE Pay: The Case Against RaCist Speech, Hate Propaganda, and PoRnography (Laura J. Lederer \& Richard Delgado eds., 1995). Much of our focus will be narrowly on the use of racial epithets in one context or another, but the use of racial epithets hardly exhausts the scope of racist speech in a broader sense. For a useful narrow definition, tying hate speech to insulting epithets, see Larry Alexander, Banning Hate Speech and the Sticks and Stones Defense, 13 CONST. COMMENT. 71, 71 (1996). Generally, such a narrow definition will suffice for our purposes herein. 
hate speech. ${ }^{2}$ The hate speech problem is, at least for the typical victims of hate speech, of practical importance. ${ }^{3}$ But of late, progress in understanding and theoretically resolving the hate speech problem has stalled. The commentators have arrayed themselves along a broad continuum of responses, in an apparently stable, unproductive fashion. ${ }^{4}$ Under these circumstances, any indirect assistance with the hate speech problem from whatever source is to be welcomed.

The choice of Gadamer and Habermas as sources of potential inspiration makes some preliminary, general sense. Each has, after all, done his share of careful reflection, over a period of time, on the use of language, and on language in the law..$^{5}$ There seems no tenet or principle within their work that delegitimizes our enterprise from the start. Habermas in particular has developed the Austinian distinction

2. Consider, for example, the grass roots efforts upon which judicial judgment was eventually passed in R.A.V. v. City of St. Paul, 505 U.S. 377 (1992); Dambrot v. Cent. Mich. Univ., 55 F.3d 1177 (6th Cir. 1995); Am. Booksellers Ass'n, Inc. v. Hudnut, 771 F.2d 323 (7th Cir. 1985); Doe v. Univ. of Mich., 721 F. Supp. 852 (E.D. Mich. 1989) (addressing, respectively, two city ordinances and three public university antidiscrimination codes).

3. Consider, as an example deliberately chosen for its atypicality, the personal experience recounted by the philosopher Wojciech Sadurski as a recent Polish immigrant to Australia. Sadurski reports that he attended, out of civic devotion, a local town council meeting at which one speaker made anti-immigrant, and, in particular, anti-Polish remarks, raising questions of child safety and town cleanliness standards. Sadurski then reports that

[S]ince the day I have heard the speech, my life has clearly been transformed for the worse. Whenever I meet my neighbours, fellow workers, or salespersons in the shops, I search for expressions of dislike or contempt in their eyes. When they are rude, I attribute it to their hatred of Poles. When they are polite, I treat it as a symptom of their patronising attitude....[M]y relationship with others can no longer be normal .... I am upset, distressed, angry and deeply offended.

Wojciech Sadurski, Offending with Impunity: Racial Vilification and Freedom of Speech, 14 SYDNEY L. REV. 163, 186 (1992). We should note in particular that the speech in this case apparently had more substantive, cognitive locutionary content than many instances of hate speech, and that Professor Sadurski is not, all things considered, a devotee of hate speech legislation. See id. at 193 ("Racists are there, and it is better to let them air their views in the open rather than allow an illusion to grow that the problem has been solved because racist statements have been made illegal.").

4. See, e.g., the gradations among academic responses to the relation between workplace harassment under Title VII of the Civil Rights Act of 1964, § 703(a)(1), 42 U.S.C. $\$ \S 2000 \mathrm{e}-2$ (1994), and the Free Speech Clause surveyed in Cynthia L. Estlund, Freedom of Expression in the Workplace and the Problem of Discriminatory Harassment, 75 TEX. L. REV. 687, 692-93 (1997). Of course, there could arise a detailed and definitive future U.S. Supreme Court opinion on possible free speech limits on Title VII, but it seems fair to say that further Supreme Court opinions on hate speech would not guarantee political, intellectual, or even legal closure on crucial hate speech issues.

5. While particularized citations will be forthcoming below, Gadamer's magnum opus is HANS-GEORG GADAMER, TRUTH AND METHOD (Joel Weinsheimer \& Donald G. Marshall trans., Continuum Publ'g 1994) (1960) [hereinafter GADAMER, TruTH AND METHOD]. A number of Habermas's works take up these broad themes. Among them, and one of the most recent, is JÜRGEN HABERMAS, BETWEEN FACTS AND NORMS: CONTRIBUTIONS TO A DISCOURSE THEORY OF LAW AND DEMOCRACY (William Rehg trans., MIT Press 1996) (1992). 
between the illocutionary and perlocutionary effects of speech ${ }^{6}$ in ways that track some standard discussions of the effects of hate speech. ${ }^{7}$ Hate speech practically begs for reference to or comparison with Habermas's theory of communicative action, ${ }^{8}$ and in particular for contrast with his ideal speech situation. ${ }^{9}$

Gadamer, on the other hand, is especially attuned to relating language, and the meaning and effects of language, to history and traditions, ${ }^{10}$ presumably not excluding traditions of verbal and other forms of racism. Gadamer is hardly inclined to argue that we should merely understand, and not apply, his theoretical work in our own contexts. For Gadamer, after all, understanding and application are inseparable; understanding is always already application. ${ }^{11}$

Our general method, which bears certain affinities to the activity described as bricolage, ${ }^{12}$ may prove worthwhile if we can steer a course between two obstructions. First, we must avoid the mistake of excessive fastidiousness in reading and interpreting Gadamer and Habermas. There is certainly every chance that neither would endorse any, let alone all, of what we may wind up saying about hate speech. The conclusions we draw about hate speech will thus not be rigorously, deductively inferable from the work of Gadamer and Habermas. But Gadamer would be unlikely to argue that his own subjective authorial intentions, at any point, must confine the

6. See, e.g., 1 JÜrgen Habermas, The Theory of COMMUNiCATIVE Action 288-90 (Thomas McCarthy trans., Beacon Press 1984) (1981).

7. See Andrew Altman, Liberalism and Campus Hate Speech: A Philosophical Examination, 103 ETHICS 302, 309 (1993) (citing J.L. AUSTIN, How TO Do THINGS WITH WORDS 98 (1962)).

8. See generally 1 HABERMAS, supra note 6.

9. See, e.g., the account in JÜRGEN HABERMAS, JUSTIFICATION AND APPLICATION: REMARKS ON DISCOURSE ETHICS 49-56 (Ciaran Cronin trans., MIT Press 1993) (1990).

10. These are major themes of the Gadamer corpus, including GADAMER, TRUTH AND METHOD, supra note 5.

11. See, e.g., id. at 308-11; David Couzens Hoy, Interpreting the Law: Hermeneutical and Poststructuralist Perspectives, 58 S. CAL. L. REv. 135, 139 (1985) (noting that for Gadamer, "interpretation is always already application"); Dennis M. Patterson, Law's Practice, 90 CoLUM. L. ReV. 575, 595 n.89 (1990) (reviewing KARL N. LLEWELlyN, THE CASE LAW SYSTEM IN AMERICA (1989)) (Gadamer as holding that "application is a necessary component of understanding"); Georgia Warnke, Law, Hermeneutics, and Public Debate, 9 Yale J.L. \& HUMAN. 395, 396 (1997) (commenting that for Gadamer, "understanding, interpretation, and application of meaning all define the same process").

12. See, following Claude Levi-Strauss, J.M. Balkin, Too Good to Be True: The Positive Economic Theory of Law, 87 COLUM. L. REV. 1447, 1487 (1987) (reviewing WILlIAM M. LANDES \& Richard A. POSNER, THE ECONOMIC STRUCTURE OF TORT LAW (1987)); Mark Tushnet, Interdisciplinary Legal Scholarship: The Case of History-in-Law, 71 CHI.-KENT L. ReV. 909, 931 (1996) (citing Claude LeVI-STRauss, The SAvage Mind 17 (1966)). 
understanding and application of his texts. ${ }^{13}$ Our conclusions can stand or fall on their own, without the implied endorsement of Gadamer and Habermas. We are, again, looking merely for inspiration, for a clearer image, or for a better turn of phrase, not for a logical premise implying a theoretical solution to the hate speech problem.

The other sort of mistake is the opposite of the first. We must avoid simply dressing up our own pre-selected insights into the hate speech problem in the distinguished regalia of Gadamer and Habermas, without gaining at least a broader, clearer, or deeper understanding. In such a case, all that is genuinely interesting and distinctive about Gadamer and Habermas plays no real functional role. Such alleged insights may, in the extreme, not in fact be particularly insightful, and neither influenced by nor worthy of association with the names of Gadamer and Habermas. The essayist Montaigne, we may point out, was complaining of a related practice when he objected to the learned who "quote Plato and Saint Thomas in matters where the first comer would make as good a witness." 14 We should instead seek to learn what Gadamer and Habermas in particular, and not necessarily any observer of the passing scene, can teach us.

\section{SElections From the AmERICAN HATE SPEECH CASE LAW: MORE QUESTIONS THAN ANSWERS}

For the sake of analytical clarity and simplicity, let us focus our attention on the admittedly distinctive case of the use of racial epithets and related racial slurs and invective. The use of racial epithets and their status in relation to the First Amendment have been judicially addressed in a number of legal contexts. Epithet speech has, for example, come into legal conflict with equal protection claims, ${ }^{15}$ section 1983 civil rights claims, ${ }^{16}$ municipal law

13. See, e.g., GADAMER, TRUTH AND METHOD, supra note 5, at 292; Francis J. Mootz III, The Ontological Basis of Legal Hermeneutics: A Proposed Model of Inquiry Based on the Work of Gadamer, Habermas and Ricoeur, 68 B.U. L. Rev. 523, 533 (1988); Brad Sherman, Hermeneutics in Law, 51 MOD. L. REV. 386, 391 (1988).

14. THE COMPLETE ESSAYS OF MONTAIGNE 624 (Donald M. Frame trans., 1958).

15. See, e.g., Williams v. Bramer, 180 F.3d 699, 706 (5th Cir. 1999).

We hold today that an officer's use of a racial epithet, without harassment or some other conduct that deprives the victim of established rights, does not amount to an equal protection violation.... Where the conduct at issue consists solely of speech, there is no equal protection violation.... We cannot conclude that his alleged conduct [one isolated comment] therefore rises to the level of harassment. 


\section{enforcement and firefighter discipline regulations, ${ }^{17}$ public university employee discipline policies, ${ }^{18}$ the common law tort of intentional infliction of severe emotional distress, ${ }^{19}$ and Title VII of the Civil Rights Act of $1964 .^{20}$}

16. 42 U.S.C. $\$ 1983$ (1994). See, e.g., Hull v. Cuyahoga Valley Joint Vocational Sch. Dist. Bd. of Educ., 926 F.2d 505, 514 (6th Cir. 1991). The court there noted that defendant's "remark was made by a decisionmaker and cannot be construed as a joke. His use of the [racial epithet] cannot be characterized as harmless or casual.... [T] he use of this word, even in jest, could be evidence of racial antipathy." Id.

17. See, e.g., Karins v. City of Atlantic City, 706 A.2d 706, 715 (N.J. 1998) (holding that a particular use of a particular racial slur in a particular context "was not remotely related to any matter of public concern" [under the test from the Pickering case] and that "the City's interest in maintaining order, discipline, harmony, and a professional working relationship... substantially outweighs Karins's right to make abusive, insulting racially motivated comments"). See Connick v. Myers, 461 U.S. 138 (1983); Pickering v. Bd. of Educ., 391 U.S. 563 (1968).

18. See, e.g., Dambrot v. Cent. Mich. Univ., 55 F.3d 1177, 1187 (6th Cir. 1995) ("Focusing on the 'content, form and context' of Dambrot's use of the [racial epithet] [under the test from the Connick case], this Court can find nothing 'relating to any matter of political, social or other concern to the community.' Dambrot's locker room speech imparted no socially or politically relevant message to his players.").

19. See, e.g., Taylor v. Metzger, 706 A.2d 685, 696 (N.J. 1998). The court in Taylor recognized that "[m]ost people [today know] that certain words are offensive and only calculated to wound." Id. (quoting Richard Delgado, Words That Wound: A Tort Action for Racial Insults, Epithets, and Name-Calling, 17 HARV. C.R.-C.L. L. REv. 133, 145 (1982) (alterations made to conform quote to original)). However, the court proceeded to note that "[a] cause of action for intentional infliction of emotional distress also requires that 'the emotional distress suffered by the plaintiff must be so severe that no reasonable [person] could be expected to endure it."' Taylor, 706 A.2d at 696 (quoting Buckley v. Trenton Saving Fund Soc'y, 544 A.2d 857, 863 (N.J. 1988)); see also Wigginton v. Servidio, 734 A.2d 798, 807 (N.J. Super. Ct. 1999).

While "a single racial slur uttered by a 'stranger on the street' could not amount to extreme and outrageous conduct [for the intentional infliction of emotional distress tort] ... courts have recognized that employees are entitled to greater protection from insults than strangers and that employers have a higher duty than strangers to avoid inflicting emotional distress... . The employer's position of authority and power over the plaintiff and the abuse of the employer-employee relationship can both contribute to a finding of extreme and outrageous conduct.

Id. (citation omitted). For further discussion, see, for example, Alcorn v. Anbro Eng'g, Inc., 468 P.2d 216, 219 n.4 (Cal. 1970) (en banc) ("Nor can we accept defendants' contention that plaintiff, as a truckdriver must have become accustomed to such abusive language."); Contreras v. Crown Zellerbach Corp., 565 P.2d 1173 (Wash. 1977) (en banc) (discussing the legal sufficiency of intentional infliction of severe emotional distress claim for employer's failure to control employees' derogatory ethnic remarks toward fellow employee).

20. Civil Rights Act of $1964, \S 703($ a)(1), 42 U.S.C. $\S 2000 \mathrm{e}-2$ (1994). The Supreme Court has, for example, recently reiterated that the "mere utterance of an ethnic or racial epithet which engenders offensive [sic] feelings in an employee would not sufficiently alter terms and conditions of employment to violate Title VII." Faragher v. City of Boca Raton, 524 U.S. 775, 787 (1998) (internal quotations and citations omitted). But see the description of Professor Sadurski's non-workplace experience, supra note 3. See also Harris v. Forklift Sys., 510 U.S. 17, 23 (1993) (apparently distinguishing crucially, for Title VII purposes, between workplace discriminatory conduct that is "humiliating" as opposed to a "mere offensive utterance"). The Court in Harris concluded that the "mere utterance of an epithet which engenders offensive feelings in an employee... does not sufficiently affect the conditions of employment to implicate Title VII." Harris, 510 U.S. at 21 (internal quotations omitted). This sort of flat, broad determination begs for reconsideration, despite its legal support in cases such as Taylor, 
Of course, the real import, if not the denotative meaning, of a racial epithet may vary depending upon factors such as the racial identities of the speaker and audience, the personal and relative power relationships among the parties, the social context and tone of the conversation, the speaker's intentions, and any listener expectations. $^{21}$ Any real understanding of epithet speech must take such considerations into proper account.

The subtleties and complications of such speech should not, however, mislead us into thinking that racial epithet speech is essentially like most other forms of speech. As one court has observed with regard to a particularly virulent racial epithet, "[t]he use of the word... automatically separates the person addressed from every non-black person; this is discrimination per se."22 The typical speaker of a racial epithet cannot entirely denature that epithet through tone of voice, facial expression, mood setting, or even express disclaimers. No speaker can thereby so easily set aside major themes of American legal and cultural history.

It has thus been argued that "[t]here are certain words and phrases 'that in the context of history carry a clear message of ... hatred, persecution, and degradation of certain groups." ${ }_{23}$ Racial

706 A.2d at 690, and Bolden v. PRC Inc., 43 F.3d 545, 551 (10th Cir. 1994) (holding two racial slurs to be insufficiently severe in the absence of "a barrage of opprobrious comments") (internal quotations omitted). The Taylor court recognized, however, that "[t]he connotation of the epithet itself can materially contribute to the remark's severity. Racial epithets are regarded as especially egregious and capable of engendering a severe impact." 706 A.2d at 690 . These tensions and inconsistencies suggest that the courts do not have a clear understanding of how to legally handle severe epithet cases, partly because they do not consistently understand how language works within an ongoing historical culture. In Title VII cases, the judicial attitude ranges broadly in assessing the relevance and weight of recourse to epithets. For some, "mere" offensive utterances are distinguished from more serious forms of discrimination or harassment. See, e.g., Hurley v. Atlantic City Police Dep't, 174 F.3d 95, 114 n.11 (3d Cir. 1999) (considering mere offensive utterance as one of a dozen possible factors in hostile work environment claims). More realistically, it has also been recognized, in contrast, that "[p]erhaps no single act can more quickly 'alter the conditions of employment and create an abusive working environment' ... than the use of an unambiguously racial epithet ... by a supervisor in the presence of his subordinates." Rodgers v. Western-Southern Life Ins. Co., 12 F.3d 668, 675 (7th Cir. 1993) (quoting Meritor Savings Bank, FSB v. Vinson, 477 U.S. 57, 67 (1986)). There is an arguable difference between at least some cases of casual, joking, egalitarian, nonauthoritative, comradely use of an epithet solely among members of the ethnic group, and even a single epithet used in earnest by a supervisor toward a work subordinate. See, e.g., Dambrot, 55 F.3d at 1180, 1187; Rodgers, 12 F.3d at 675 . Epithets do vary in their tone and import depending upon the identities of the speakers, audience, and context. See, e.g., the circumstances discussed in Dambrot, 55 F.3d at 1180, 1187.

21. See supra note 20.

22. Bailey v. Binyon, 583 F. Supp. 923, 927 (N.D. Ill. 1984).

23. Karins v. City of Atlantic City, 706 A.2d 706, 720 (N.J. 1998) (quoting State v. Vawter, 642 A.2d 349, 354 (N.J. 1994) (quoting Mari J. Matsuda, Public Response to Racist Speech. Considering the Victim's Story, 87 MICH. L. REV. 2320, 2365 (1989))). 
epithet speech therein differs from some other forms of hostile speech: "[r]acial insults are different qualitatively because they conjure up the entire history of racial discrimination in this country." "24 We shall briefly discuss below ${ }^{25}$ the relationship between this inevitable verbal "conjuring up" of an entire historical tradition and the logic of freedom of speech.

The cases have given us this and much else to think about. It seems plain enough that threats of violence based on racial identity can impair, rather than promote, genuine free speech in the sense of an uninhibited exchange of ideas. ${ }^{26}$ Can we then go on to say that racial epithets undermine, or fail to contribute to, the robust exchange of social ideas, even where no explicit threat of violence is issued? Should such epithets be classified as contributions, or even attempts to contribute, to any ongoing public discussion? What is their value for free speech purposes, against which we might weigh any harassing or discriminatory tendencies such speech might carry? Do racial epithets constitute speech on a matter of public interest or concern, against which we might balance any countervailing public interests? Are there senses in which racial and other epithets send, expressly or impliedly, a constitutionally relevant message? Do racial epithets always or ever carry social messages independent of their propensity to wound? In what ways, if any, is it legitimate for courts or legislatures to judge the constitutional free speech value of the language of such epithets? Are there any appropriate grounds for legally restricting epithet speech that do not simply reflect disagreement with the speech's content or point of view?

\section{SOME RESPONSES FROM THE ACADEMIC LITERATURE}

Hate speech obviously implicates, in one way or another, values such as freedom, equality, and dignity. ${ }^{27}$ The academic commentators on hate speech often differ as to possible conflicts among these

24. Taylor, 706 A.2d at 695 (quoting Delgado, supra note 19, at 157); see also Williams v. Tri-County Metro. Trans. Dist., 958 P.2d 202, 205 n.3 (Or. Ct. App. 1998) (citing Delgado, supra note 19 , at 157). This is certainly not to suggest that no other category of speech other than a racial epithet could summon a historical theme in its entirety, but racial epithets may in this regard differ from many forms of generally hostile speech.

25. See infra notes $35-45$ and accompanying text.

26. See, e.g., State v. Talley, 858 P.2d 217, 226 (Wash. 1993) (en banc) ("Experience shows that threats of violence based on personal characteristics or group identity cause deep individual and societal harm and that they diminish, rather than enhance, the exchange of ideas in a free society.") (internal quotation omitted).

27. See generally Delgado, supra note 19. 
values. ${ }^{28}$ It is even possible to argue that these values actually do not conflict in the hate speech context, and that they all point unequivocally in favor of either restricting hate speech, or not restricting hate speech. In any event, it is fair to say that the academic commentators often end up focusing largely on the consequences of hate speech. ${ }^{29}$

To begin with, racial epithets often convey, if only implicitly or via some sort of cultural shorthand, "the message that distinctions of race are distinctions of merit, dignity, status, and personhood." 30 Verbal responses to such epithets, the classic "more speech" 31 remedy, are commonly futile, irrelevant, dangerous, or impossible. ${ }^{32}$ Crucially, racial insults are typically "not intended to inform or convince the listener." 33 As Professor Richard Delgado concisely puts the point, "Racial insults invite no discourse." 34 Racial insults that neither seek to inform, nor to invite any responsive discourse, are not, however, without their evocative associations. Such insults, as we have seen, "conjure up the entire history of racial discrimination in this country." 35 As Professor Charles Lawrence reports, no such

28. Compare, e.g., Delgado, supra note 19, and Charles R. Lawrence III, If He Hollers Let Him Go: Regulating Racist Speech on Campus, 1990 DUKE L.J. 431, with Alexander, supra note 1 , at 73 ("[P] aradigmatic hate speech, if harmful, is harmful only in ways that cannot justify its prohibition without gutting our constitutional conception of freedom of speech."). See also Dana Moon Dorsett, Hate Speech Debate and Free Expression, 5 S. CAL. INTERDISC. L.J. 259 (1997); Calvin R. Massey, Hate Speech, Cultural Diversity, and the Foundational Paradigms of Free Expression, 40 UCLA L. REV. 103 (1992); Sadurski, supra note 3. See in particular the pointed debate between Professors Delgado and Gey in Steven G. Gey, The Case Against Postmodern Censorship Theory, 145 U. PA. L. REV. 193 (1996); Richard Delgado, Are HateSpeech Rules Constitutional Heresy?: A Reply to Steven Gey, 146 U. PA. L. REV. 865 (1998); Steven G. Gey, Postmodern Censorship Revisited: A Reply to Richard Delgado, 146 U. PA. L. REV. 1077 (1998) [hereinafter Gey, Postmodern Censorship Revisited].

29. See, e.g., Delgado, supra note 19, at 135-47.

30. Id. at 136 .

31. See Whitney v. California, 274 U.S. 357, 372, 377 (1927) (Brandeis, J., concurring), overruled on other grounds by, Brandenburg v. Ohio, 395 U.S. 444 (1969).

32. See Delgado, supra note 19, at 146.

33. Id. at 177; see also Delgado, supra note 28, at 872; Kent Greenawalt, Insults and Epithets: Are They Protected Speech?, 42 RUTGERS L. REV. 287, 293 (1990) (An epithet speaker "does not use words to inform, nor is he really attempting to indicate his feelings. His aim is to wound...."); Kenneth D. Ward, Free Speech and the Development of Liberal Virtues: An Examination of the Controversies Involving Flag-Burning and Hate Speech, 52 U. MIAMI L. REV. 733, 768 (1998) (discussing hate speakers as expressing "no interest in participating in discussion" or deliberation, and as neither engaging with audience ideas nor seeking any response, as opposed to silence or intimidation). Professor Peter Byrne defines racial insults precisely to exclude "rational but offensive propositions that can be disputed by argument and evidence." J. Peter Byrne, Racial Insults and Free Speech Within the University, 79 GEO. L.J. 399, 400 (1991).

34. Delgado, supra note 19 , at 177.

35. Id. at 157. Thus the effects of epithets directed at different target groups will vary in nature and intensity, depending upon the varying histories of discrimination against the groups 
verbal racial incident is truly "isolated," 36 and any such use of racial epithets may "evoke in you all of the millions of cultural lessons regarding your inferiority that you have so painstakingly repressed." ${ }_{37}$

It is thus a mistake to include typical epithet speech within the classic free speech paradigm of an exchange of popular, or unpopular, social ideas ${ }^{38}$ aimed at informing or persuading, immediately or over time, at least some portion of one's audience. Epithet speech may well have other functions not only different from, but entirely incompatible with, the familiar exchange of social ideas paradigm. We must thus be alert to what epithet speech actually does, and to its actual role within lived human experience. ${ }^{39}$ Epithet speech has understandably been said to partake more of action than of expression. ${ }^{40}$ Professor Kent Greenawalt thus refers to at least some epithet speech as, to a degree, "situation-altering," ${ }_{41}$ as opposed to purely expressive. ${ }^{42}$ The intention behind such speech may thus be to wound, ${ }^{43}$ humiliate, ${ }^{44}$ or otherwise inflict pain rather than to communicate a social idea in any classically discursive sense. ${ }^{45}$

Speech thus may have a number of different kinds of functions and effects. Some writers have sought to distinguish between the illocutionary effects and the perlocutionary effects of speech. ${ }^{46}$ Illocutionary effects are, roughly, those that are accomplished in the very act of uttering the words in a certain context or with a certain intent, as in the case of making a promise, being deputized, or issuing

in question. See, e.g., Steven H. Shiffrin, Racist Speech, Outsider Jurisprudence, and the Meaning of America, 80 CORNELL L. REV. 43, 81 (1994).

36. Lawrence, supra note 28 , at 461.

37. Id.

38. See Massey, supra note 28 , at 194.

39. See Greenawalt, supra note 33, at 287-88. Compare Wittgenstein's famous emphasis on language as it is actually used in the world. See LuDWIG WITTGENSTEIN, PHILOSOPHICAL INVESTIGATIONS 48e § 116 (G.E.M. Anscombe trans., Prentice Hall 3d ed. 1958) (1953).

40. See Greenawalt, supra note 33 , at 290-93.

41. See id. at 290,292 . There is probably a sense, though, in which all instances of (understood or even misunderstood) speech are "situation-altering," or are at least situation "altering" in the broad sense of tending either to somehow alter or else preserve a situation. Any ordinary conversation tends at a minimum to reinforce our previous assessment of our interlocutor's worthiness or competencies.

42. See id. at 290.

43. See Delgado, supra note 19.

44. See Greenawalt, supra note 33, at 293.

45. See, e.g., Robert C. Post, Community and the First Amendment, 29 ARIZ. ST. L.J. 473, 480 (1997) ("The marketplace of ideas ... does not justify protecting expression that is intended merely to injure and not to contribute to truth ....").

46. This distinction is traceable to AUSTIN, supra note 7, at 95-108. 
a threat. ${ }^{47}$ Perlocutionary effects are said to be those accomplished by means of one's speech, through a causal effect on one's audience, as in the case of speech that induces audience reliance, trust, fright, or anger. ${ }^{48}$

This distinction between illocutionary and perlocutionary effects may not be strict, or even terribly viable. ${ }^{49}$ If hate speech evokes or conjures up a racist tradition, ${ }^{50}$ should we say, for example, that such a result is an illocutionary, or else a perlocutionary, effect of the speech? Either answer is defensible. Even if the distinction is thus not clear, however, the very idea that speech may have effects that do not depend upon, or are not limited to, the agreement or disagreement of any listener with the propositional content of the speech may help us to better understand the nature of hate speech. ${ }^{51}$

It is certainly not difficult to think of examples of racist speech with clear and undeniable illocutionary or perlocutionary effects. The drive-by hurling of a racial epithet at a lone pedestrian may, as we have seen, evoke or conjure up an historical tradition, ${ }^{52}$ at least some of which will take the form of illocutionary or perlocutionary effects. We should not, however, discount the illocutionary or perlocutionary effects of even refined, technical, and abstract discussions of race.

In our culture, for example, even the theoretical discussion of race and alleged native general intelligence ${ }^{53}$ inevitably involves important illocutionary or perlocutionary effects. Some of these effects may be unintended, or even unrecognized. They may vary in

47. See, e.g., Stephen M. Feldman, Principle, History, and Power: The Limits of the First Amendment Religion Clauses, 81 IOWA L. REV. 833, 850 n.87 (1996) (reviewing NAOMI W. COHEN, JeWS IN CHRISTIAN AMERICA: THE PURSUTT OF RELIGIOUS EquAlity (1992) and STEVEN D. SMITH, FOREORDAINED FAILURE: THE QUEST FOR A CONSTITUTIONAL PRINCIPLE OF RELIGIOUS FREEDOM (1995)).

48. See id.; Gary L. Francione, Experimentation and the Marketplace Theory of the First Amendment, 136 U. PA. L. REV. 417, $431 \mathrm{n} .49$ (1987). While the focus is normally on those perlocutionary effects that depend upon an understood message, or on the content of the speech, speech can have perlocutionary effects apart from any understood content, as in the case of someone who is frightened or alerted by the mere sound of a voice.

49. Cf. Judith Butler, Burning Acts: Injurious Speech, 3 U. CHI. L. SCH. ROUNDTABLE 199, 199 (1996) (referring to the distinction between illocutionary and perlocutionary effects as "tricky, and not always stable").

50. See supra notes 35-37 and accompanying text.

51. For relevant discussion, see, for example, Alexander, supra note 1, at $87-89$ (discussing Altman, supra note 7); Altman, supra note 7, at 309-10; Butler, supra note 49, at 199, 202.

52. See supra notes 35-37 and accompanying text.

53. See, e.g., Richard J. Herrnstein \& Charles Murray, The Bell Curve: INTELLIGENCE AND CLASS STRUCTURE IN AMERICAN LIFE (1994). For a sense of some of the responsive discussion, see, for example, THE BELl CuRVE WaRs: RACE, INTELligenCE, AND THE FUTURE OF AMERICA (Steven Fraser ed., 1995). 
intensity and direction. But we should recognize that such a discussion, however apparently abstract and detached, may have effects such as (yet again) putting entire groups of people under special scrutiny, casting suspicion, putting such groups on the defensive, or even reinforcing traditional stereotypes, quite apart from the merits of any scientific argument or of anyone's agreement or disagreement therewith. The illocutionary or perlocutionary effects of such speech may, at least in some given cases, far outweigh, in their social significance, any effect that is mediated by agreement or disagreement with such speech. ${ }^{54}$

In general and in various particular contexts, ${ }^{55}$ though, the academic commentary on the hate speech problem remains badly fractured. ${ }^{56}$ Those particularly critical of legal restrictions on hate speech emphasize concerns regarding slippery slopes and dangerous precedents, ${ }^{57}$ backfiring intentions,${ }^{58}$ administrative incompetence and unpredictability, ${ }^{59}$ the risks of superficially repressing racism, ${ }^{60}$ and

54. This possibility seems underdiscussed in, for example, Alexander, supra note 1, at 8789 , and Altman, supra note 7, at 309-10.

55. See the disparate commentary on free speech issues in the context of workplace Title VII hostile environment actions as discussed in, for example, Kingsley R. Browne, Title VII As Censorship: Hostile-Environment Harassment and the First Amendment, 52 OHIO ST. L.J. 481 (1991); Kingsley R. Browne, Workplace Censorship: A Response to Professor Sangree, 47 RUTGERS L. REV. 579 (1995); Deborah Epstein, Free Speech at Work: Verbal Harassment As Gender-Based Discriminatory (Mis)Treatment, 85 GEO. L.J. 649 (1997); Estlund, supra note 4; Richard H. Fallon, Jr., Sexual Harassment, Content Neutrality, and the First Amendment Dog That Didn't Bark, 1994 SUP. CT. REV. 1; David B. Oppenheimer, Workplace Harassment and the First Amendment: A Reply to Professor Volokh, 17 BERKELEY J. EMP. \& LAB. L. 321 (1996); Suzanne Sangree, Title VII Prohibitions Against Hostile Environment Sexual Harassment and the First Amendment: No Collision in Sight, 47 RUTGERS L. REV. 461 (1995); Eugene Volokh, Thinking Ahead About Freedom of Speech and Hostile Work Environment Harassment, 17 BeRKeley J. EMP. \& LAB. L. 305 (1996); Eugene Volokh, What Speech Does "Hostile Work Environment" Harassment Restrict?, 85 GEO. L.J. 627 (1997).

56. See, e.g., supra note 28.

57. See, e.g., Alexander, supra note 1, at 93 ("[A] ban on 'epithets' will shade naturally into a ban on the ideas of subhuman, contemptible status that epithets express."); Gey, Postmodern Censorship Revisited, supra note 28, at 1082-84 ("Once the postmodern censors sweep away strict restrictions on the regulation of antisocial expression, they will have little protection when political activists with whom they sympathize have their own speech declared antisocial."); Sadurski, supra note 3, at 194 (discussing the possibility of hate speech legislation's being used to silence the disadvantaged).

58. See, e.g., supra note 57; see also Alexander, supra note 1, at 93 ("[I]f a list of specific words is banned, undoubtedly new words will begin functioning as epithets.").

59. See Frederick Schauer, Discourse and Its Discontents, 72 NOTRE DAME L. REV. 1309, 1321 (1997) (questioning "whether the interventions of admittedly non-ideal governments can systematically be expected to be more harmful to the truth-finding process than the distortions occasioned by the operation of equally non-ideal inequalities and other misuses of communicative power in the deliberative setting").

60. See, e.g., Alexander, supra note 1, at 79 ("[B]anning hate speech often leaves the hateful attitudes and beliefs intact and just creates the illusion that they have disappeared."); Dorsett, supra note 28, at 292 ("Critical race theorists, while emphasizing the harms of racist 
discrimination among different forms of racist speech or different classes of racist speakers. ${ }^{61}$ Those more sympathetic to restrictions on hate speech, correspondingly, reject or minimize the likelihood or the moral weight of such concerns, perhaps in light of differing value priorities.62 Below, we shall draw upon the work of Gadamer and Habermas to clarify and reinforce certain themes and to minimize or bypass others, with an eye toward theoretical progress on the hate speech problem.

\section{GADAMER AND THE NATURE AND STATUS OF HATE SPEECH}

Let us admit that there is something odd about turning to HansGeorg Gadamer for understanding of hate speech. It is vaguely like turning to Gandhi for insight into hate itself. We might well say that if there is any sort of discourse that is the diametric opposite of hate speech, it is embodied in Gadamer's work, as in, to choose merely one example, his approach to the basic Aristotelian texts. ${ }^{63}$ At the very least, though, perhaps we can learn or more vividly appreciate something about hate speech through this especially stark contrast. Beyond Gadamer's sheer exemplariness, though, we can more fully appreciate the real nature and status of hate speech through some of Gadamer's central concerns, including for tradition and the so-called "history of effect," and for one's approach to one's own prejudices in genuinely fruitful interchange and understanding. ${ }^{64}$

Gadamer can, for example, offer some perspective on the unusual nature of the most virulent racial epithets. It has been rightly observed that often, such epithets do not themselves literally convey any intended general social idea, ${ }^{65}$ and are certainly no essential part

speech, ignore the potential harm of inflamed repressed racism."); Sadurski, supra note 3, at 193.

61. See Alexander, supra note 1, at 78 ("Banning epithets, but not skillful rhetorical skewerings, would essentially and unjustifiably discriminate against low-brow forms of expression."); see also id. at 92. We would of course want to investigate whether the various psychological and other effects of crude and refined or subtle racist speech might significantly differ.

62. See, e.g., MATSUDA ET AL., supra note 1.

63. See generally HANS-Georg Gadamer, The IdEA of THE GoOd IN PlatonicARISTOTELIAN PHILOSOPHY (P. Christopher Smith trans., 1986) [hereinafter GADAMER, IDEA OF THE GOOD].

64. While these concerns run throughout the Gadamerian corpus in general, the central single focus would be Truth and Method. GADAMER, TRUTH AND METHOD, supra note 5. For more on the dualistic, necessary, and constructive, yet limiting nature of Gadamerian prejudice, see Graeme Nicholson, Truth in Metaphysics and in Hermeneutics, in THE PHILOSOPHY OF HANS-GEORG GADAMER 309, 317 (Lewis Edwin Hahn ed., 1997).

65. See supra notes $33-45$ and accompanying text. 
of any exposition of intended general social ideas. ${ }^{66}$ How can we best account, then, for the sometimes psychologically devastating effects of such epithets, typically in accordance with the speaker's intentions? ${ }^{67}$ How can epithet speech in some sense not itself articulate any social idea, and yet in another sense somehow convey enough meaning to foreseeably pack a psychological punch?

It seems justifiable to think of this important duality of epithet speech in Gadamerian terms. Gadamer's work helps us appreciate how hate speech that is in a legally important sense ideationally barren can evoke or conjure up an entire racist historical tradition. ${ }^{68}$ Gadamer explores with unusual acuity how "history affects and indeed effects consciousness." 69 The hurling of a racial epithet is not an isolated event. ${ }^{70}$ It is in a sense a discrete verbal act, ${ }^{71}$ but it is as much an act in history as the recounted story of a lynching, or the actual lynching itself, or all lynchings collectively. Gadamer clarifies for us how "every event is effected by history," 72 how it inescapably has its own pre-history, ${ }^{73}$ and how it "does not appear ex nihilo." 74 Typically, the target of a racial epithet does not react psychologically to such an epithet as though its use were historically contextless. ${ }^{75}$ The epithet itself has a history, which helps explain why racists cannot just immediately mint new, but equally effective racial epithets, just to keep one step ahead of legal restrictions on traditional epithet speech.

Inexorably, both the epithet speaker and target are situated within historical traditions. ${ }^{76}$ On Gadamer's understanding, our traditions are multiple ${ }^{77}$ and are crucially verbal..$^{78}$ There are certainly

66. This language is suggested by Chaplinsky v. New Hampshire, 315 U.S. 568, 572 (1942).

67. See supra notes 35.45 and accompanying text.

68. See supra notes $24,35-37$ and accompanying text.

69. JOEL C. WEINSHEIMER, GADAMER'S HERMENEUTICS: A READING OF TRUTH AND METHOD 13 (1985).

70. See supra note 36 and accompanying text.

71. See supra notes $41-54$ and accompanying text.

72. WEINSHEIMER, supra note 69 , at 199 .

73. See id.

74. Id.

75. See supra note 37 and accompanying text.

76. See, e.g., GADAMER, TRUTH AND METHOD, supra note 5, at 276, 295. It has been observed that "the operative force of tradition over interpretation is what Gadamer calls the work of 'effective-history." Sherman, supra note 13, at 390 . This does not mean, however, that we are simply trapped within our traditions, as flies in amber. Tradition evolves and is determined through our participative exertions. See GADAMER, TRUTH AND METHOD, supra note 5, at 293; Mootz, supra note 13, at 537.

77. See David Couzens Hoy \& Thomas MCCarthy, CRITICAl Theory 197 (1994) (interpreting Gadamer as holding not that tradition is unitary or homogeneous, but "multifarious," with the result that there are many and diverse operative traditions); Lawrence 
American cultural and legal traditions embodying some forms of pluralism and racial egalitarianism, as reflected in the language of the Declaration of Independence ${ }^{79}$ and the Emancipation Proclamation. ${ }^{80}$ But it must also be said that there are American traditions of inegalitarianism, white supremacy, race baiting, and sheer racial violence as well. ${ }^{81}$ To react to a racial epithet is, in a sense, to recognize that the epithet is embedded in, ${ }^{82}$ and draws most if not all of its real meaning from, ${ }^{83}$ an ongoing historical tradition.

Gadamer's work is equally useful in clarifying how radically hate speech differs from any sort of attempt at genuine communication and understanding. These radical differences help show why legally restricting racial invective differs crucially from censoring the communication of distasteful opinions or from attempts to persuade an audience to adopt unpopular beliefs. Through Gadamer's work, we can better appreciate why hate speech regulation need not significantly impinge upon the communicative processes at the heart of the First Amendment.

Gadamer argues that "[g]enuine speaking, which has something to say and hence does not give prearranged signals, but rather seeks words through which one reaches the other person, is the universal human task." 84 What Gadamer refers to here as "genuine speaking" thus requires an attempt to "reach" an audience. Of course, an epithet hurler doubtless "reaches" an audience in the crude sense of

Byard Solum, Freedom of Communicative Action: A Theory of the First Amendment Freedom of Speech, 83 Nw. U. L. Rev. 54, 66 (1989) ("[O]ur pluralistic culture" is, per Gadamer, "constituted by a multiplicity of traditions.").

78. See GADAMER, TRUTH AND METHOD, supra note 5, at 389 ("[T]radition is essentially verbal in character.").

79. See THE DECLARATION OF INDEPENDENCE para. 2 (U.S. 1776) (stating "that all men are created equal").

80. See Abraham Lincoln, Emancipation Proclamation (Jan. 1, 1863), in NEAL H. COGAN, CONTEXTS OF THE CONSTITUTION: A DOCUMENTARY COLlECTION ON PRINCIPLES OF AMERICAN CONSTITUTIONAL LAW 653, 654 (1999) ("[A]ll persons held as slaves ... shall be then thenceforward, and forever free.").

81. See, for example, the discussion in Forsyth County, Ga. v. Nationalist Movement, 505 U.S. 123, 124-26 (1992) (briefly discussing the twentieth-century racial history of Forsyth County). More broadly, see JOHN EGERTON, SPEAK NOW AGaINST THE DAY: THE Generation BeFore THE Civil RIghts MOVEMENT IN THE SOUTH (1994); RICHARD KLUGER, SIMPLE JUSTICE: THE HISTORY OF BROWN V. BOARD OF EDUCATION AND BLACK AMERICA'S STRUGGLE FOR EQUALITY (1977).

82. See GADAMER, TRUTH AND METHOD, supra note 5, at 296 ("[T]he text belongs to the whole tradition whose content interests the age and in which it seeks to understand itself.").

83. See id. at 300 (referring to the "history of effect" as "the reality and efficacy of history within understanding itself"). 1976).

84. Hans-Georg Gadamer, Philosophical Hermeneutics 17 (David E. Linge trans., 
provoking an adverse, unwelcome emotional reaction, or of evoking grisly historical traditions. Gadamer, however, refers to "reaching" an audience in a rather different sense.

For Gadamer, any attempt at genuine understanding requires a state of mind essentially antithetical to that of the epithet hurler ${ }^{85}$ In a genuine conversation, both interlocutors want to understand, ${ }^{86}$ and they seek a mutual, ${ }^{87}$ and perhaps mutually transformative, ${ }^{88}$ understanding. Genuine conversation is a process that requires a certain tentativeness and openness, ${ }^{89}$ a mutual vulnerability,,$^{90}$ and a sense of the value of diverse perspectives ${ }^{91}$ in light of one's own fallibility and limitations. ${ }^{92}$

85. For classic general discussion, see T.W. ADORNo ET AL., THE AUTHORITARIAN Personality (1969); Gordon W. AlLPORT, ThE NATURE OF PREJUdiCE (Anchor Books 1958) (1954); JeAN-PAul SARTRE, ANTI-SEMITE AND JEW (George J. Becker trans., Schocken Books 1948) (1946). This state of mind is in dramatic contrast with Gadamer's approach to genuine conversation as requiring an attempt at mutual understanding, mutual openness, mutual risk, mutual respect, mutual recognition, and a mutual sense of worthiness. See RICHARD J. BERNSTEIN, BEYOND OBJECTIVISM AND RELATIVISM: SCIENCE, HERMENEUTICS, AND PRAXIS 162 (1983).

86. See WEINSHEIMER, supra note 69 , at 209 ; Sherman, supra note 13 , at 394

87. See WEINSHEIMER, supra note 69, at 209; Sherman, supra note 13, at 394 . The idea of mutuality may also be expressed as "give-and-take." See Francis J. Mootz III, Law in Flux: Philosophical Hermeneutics, Legal Argumentation, and the Natural Law Tradition, 11 YALE J.L. \& HUMAN. 311, 315 (1999).

88. See WeINSHEIMER, supra note 69 , at 209 ; Mootz, supra note 13 , at 536 ; Sherman, supra note 13, at 394; see also HANS-GEORG GADAMER, REASON IN THE AGE OF SCIENCE 110 (Frederick G. Lawrence trans., 1981) ("Discussion bears fruit when a common language is found. Then the participants part from one another as changed beings. The individual perspectives with which they entered upon the discussion have been transformed, and so they are transformed themselves."). Again, there is certainly a depraved sense in which a racial slur can promote a transformation, and perhaps even a transformation of both speaker and victim, or of their relationship. This sort of transformation is, of course, not the product of any cooperative endeavor, or of any genuinely open-minded search for unattained insights.

89. See, e.g., PAUL CHEVIGNY, MORE SPEECH 72 (1988) (characterizing Gadamerian openness as a "listening stance"); HANS-GEORG GADAMER, PRAISE OF THEORY: SPEECHES AND ESSAYS 72 (Chris Dawson trans., Yale Univ. Press 1998) (1983) (discussing Gadamer on the ability to recognize truth as itself requiring "an open mind"-as is presumably uncharacteristic of the typical epithet hurler); Sherman, supra note 13, at 392-93 (requiring openness to text and to other interlocutors); Georgia Warnke, Reply to Greenawalt, 9 YALE J.L. \& HUMAN. 437, 439 (1997).

90. See GADAMER, supra note 88, at 100; cf. BERNSTEIN, supra note 85 , at 144 ("It is through the fusion of horizons that we risk and test our prejudices."); GADAMER, TRUTH AND METHOD, supra note 5, at 269 ("A person trying to understand a text is prepared for it to tell him something."); PAUl RICOEUR, HeRMENEUTICS AND THE HuMAN SCIENCES 76 (John B. Thompson ed., 1981) (For Gadamer, "only insofar as I place myself in the other's point of view do I confront myself with my present horizon, with my prejudices."); Sherman, supra note 13, at 392-93.

91. See, e.g., GADAMER, IDEA OF THE GOOD, supra note 63, at xxxi ("[A]ll the while aiming to shed light on it from a variety of perspectives, but fully acknowledging that the insights gained in this way will of necessity be inconclusive and unsystematic."); Michael $\mathrm{J}$. Perry, Constitutional Judgment As Moral Judgment: A Brief Comment, 61 U. CoLo. L. REV. 
Of course, it is open to the epithet hurler to announce that he does not care to thus put into play, or to put at risk, any of his most virulent prejudices. He does not seek to inquire or to attain any degree of genuine openness or mutual vulnerability. He is indifferent to the hermeneutic task, or to what Gadamer refers to as "genuine speaking." $" 93 \mathrm{He}$ does not at all seek to understand, to persuade, or to reach agreement. His purpose is more visceral. He seeks to use words as a kind of club, or better, as a whip that leaves permanent scars.

By way of response, we could, presumably, admit that the epithet hurler and the Gadamerian hermeneuticist have very little overlap of horizons, and that they are simply playing different language games. What sense would it make, by way of analogy, to judge the gladiator by the standards pertaining to the magician, or vice versa? Ultimately, though, there is little justification for our constitutionally deferring to the epithet hurler's inversion of and contempt for Gadamerian values.

We need not protect the epithet hurler because the basic purposes underlying the Free Speech Clause, whatever they are, need not be construed as neutral as between him and the Gadamerian inquirer. By way of loose analogy, we need not construct a theory of maturity such that everyone who wants to be thought of as mature turns out, on our theory, to be equally mature. This conclusion does not concern anyone's ideological bias or bias against any attempt at the articulate expression and coherent defense of disfavored ideas. We certainly need not claim that Gadamer's account of hermeneutics sets the minimum baseline for free speech protections. Such a

803, 807 (1990); Sherman, supra note 13, at 393 (arguing that a conversational partner must grant the possible superiority of the other partner's position).

92. See GADAMER, IDEA OF THE GOOD, supra note 63, at xxxi ("We cannot ascertain an indubitably secured starting point; we cannot know ahead of time where a philosophical discussion will lead us, and we will never be able to say that we have arrived at a definitive conclusion."); $c f$. WEINSHEIMER, supra note 69, at 166-67 (envisioning an inquiring interlocutor as one who proposes an initial possibility, with an appreciation of the role of the unexpected, and an openness to revision of some of one's initial prejudices). We should also note Gadamer's concern to detect and remedy the social and other conditions that tend to block or frustrate such egalitarian conversational inquiry. See BERNSTEIN, supra note 85, at 163. For Habermas's general agreement on this point, see infra note 123.

93. See GADAMER, supra note 84 , at 17 . This does not imply that only Gadamer can lead us to see these contrasts. Habermas in particular essentially follows Gadamer in this regard. See HOY \& MCCARTHY, supra note 77, at 188 ("Habermas acknowledges Gadamer's Truth and Method as the source for Habermas's thesis that the telos of human language is reaching understanding and agreement."). 
standard would, after all, amount to a baseline few speakers could meet.

If there are, nevertheless, some basic purposes underlying the Free Speech Clause-reasons why we typically wish to protect much popular or unpopular verbal expression-there is no reason to assume that any such reasons justify protection of hate speech. Those purposes do not cohere as well with the nature and effects of epithet spewing as with ordinary political discourse, however emotional or intemperate, let alone as well as with the practice of an ideal hermeneutic inquirer. Epithet speech may, on the most neutral understanding, simply not cohere with the acknowledged purposes underlying the Free Speech Clause.

We value free speech for its contributions, for example, to the flourishing of rich personal and intellectual development, ${ }^{94}$ to the serious, dialogic exchange of ideas, of whatever stripe, bearing upon the conduct of a representative democratic government, ${ }^{95}$ to the earnest, ongoing pursuit of truth under conditions of inevitable human fallibility, ${ }^{96}$ to teaching tolerance, ${ }^{97}$ or for other basic purposes. Yet we may find little or no reason to bring the typical instance of epithet hurling within the scope of Free Speech Clause coverage in the first place. Gadamer's account of conversation, and even of idealized hermeneutic inquiry, help us more fully appreciate this concept.

In particular, unlike today's pessimists, we need not assume that our racist and other unworthy traditions are frozen permanently and

94. See, e.g., ThOMAS I. EMERSON, TOWARD a GENERAL ThEORY OF THE FirsT AMENDMENT 3 (1966); Martin H. Redish, The Value of Free Speech, 130 U. PA. L. ReV. 591, 593 (1982). The classic, and still most valuably provocative, discussion of this rationale for free speech remains JoHN STUART MILL, ON LIBERTY (David Spitz ed., 1975). See also Kent Greenawalt, Free Speech Justifications, 89 COLUM. L. REV. 119 (1989); Brian C. Murchison, Speech and the Self-Realization Value, 33 HARV. C.R.-C.L. L. REV. 443 (1998).

95. See, e.g., EMERSON, supra note 94, at 3; AleXANDER MEIKLEJOHN, FREE SPEech AND ITS RELATION TO SElf-GOVERNMENT 93-94 (1948); C. Edwin Baker, The Process of Change and the Liberty Theory of the First Amendment, 55 S. CAL. L. REV. 293 (1982); Cass R. Sunstein, Free Speech Now, 59 U. CHI. L. REV. 255 (1992).

96. See, e.g., EMERSON, supra note 94, at 3; MILL, supra note 94, at 17-52; William P. Marshall, In Defense of the Search for Truth As a First Amendment Justification, 30 GA. L. REV. 1 (1995); Steven D. Smith, Skepticism, Tolerance, and Truth in the Theory of Free Expression, 60 S. CAL. L. REV. 649 (1987). For a discussion of Gadamer's intersubjective, rather than classically objective, account of truth, see William N. Eskridge, Jr., Gadamer/Statutory Interpretation, 90 COLUM. L. REV. 609, 615 (1990). See also GADAMER, TRUTH AND METHOD, supra note 5, at 490 ("[T]here is ... no understanding that is free of all prejudices, however much the will of our knowledge must be directed toward escaping their thrall.").

97. See lee C. Bollinger, The Tolerant Society: Freedom of Speech and EXTREMIST SPEECH IN AMERICA (1986); Vincent Blasi, The Teaching Function of the First Amendment, 87 COLUM. L. REV. 387 (1987) (reviewing BOLLINGER, supra). 
unalterably into our culture. It is possible, for Gadamer, to confront and alter such traditions and prejudices, rather than passively accepting them as beyond legal redress. If epithet speech is typically both intended and received in something of an assaultive or inflictive fashion, loosely parallel to the use of a bullwhip, we should not be startled to find that such speech is far removed from the Gadamerian paradigm. Furthermore, such speech is excluded from even less demanding paradigms and also falls outside the scope of First Amendment protection. Gadamer's account of the hermeneutic process certainly does not set the minimum standard for what should count as protected speech. Rather, that account merely throws into clearer relief, by way of contrast, the sorts of speech, independent of any associated ideas, that do and do not fall within the purposedelimited scope of the Free Speech Clause.

\section{HABERMAS AND THE GULF BETWEEN IDEAL SPEECH AND HATE SPEECH}

Whatever divergences we may find here or elsewhere between Gadamer and Habermas, Habermas clearly owes much to Gadamer. Habermas received from Gadamer much of his crucial concern for the use of language to reach genuine understanding and agreement, ${ }^{98}$ as opposed to the use of language to assault, alienate, or intimidate. ${ }^{99}$

98. See HoY \& MCCARTHY, supra note 77, at 188; see also, e.g., JÜRGEN HABERMAS, THEORY AND PRACTICE 17 (John Viertel trans., Polity Press 1988) (1971) ("II]n every speech act the telos of reaching an understanding ... is already inherent.").

99. Merely for simplicity of exposition, we will refer mainly to Habermas, but much of the argument below could be developed through focusing on other writers, including Robert Alexy and Karl-Otto Apel. See, e.g., Robert Alexy, A Theory of Practical Discourse, in THE Communicative Ethics ConTroversy 151, 166 (Seyla Benhabib \& Fred Dallmayr eds., 1990) ("Whoever justifies something at least pretends, at least with regard to the justification, to accept the other person as equal partner in justification and neither to exercise constraint nor to support constraint exercised by others."); Karl-Otto Apel, Is the Ethics of the Ideal Communication Community a Utopia? On the Relationship Between Ethics, Utopia, and the Critique of Utopia, in THE COMMUNICATIVE ETHICS CONTROVERSY, supra, at 23, 43 (asserting a "pragmatic self-contradiction" to afflict an assertion such as "I hereby assert as true that I am not obliged in principle to recognize all possible members of the unlimited community of argumentation as having equal rights"); id. at 55 ("[R]esponsible politics stands ... under the regulative principle of a long-term strategy of the realization of the formal preconditions for an ideal community of communication at all levels of human interaction."); id. at 48 (referring to "the normative preconditions of ideal communication, whose empirical realization in a concrete society must indeed also be subject to additional preconditions of historical ... concrete institutions and conventions"); Karl-Otto Apel, Regulative Ideas or Truth-Happening?: An Attempt to Answer the Question of the Conditions of the Possibility of Valid Understanding, in THE PHILOSOPHY OF HANS-GEORG GADAMER, supra note 64, at 67, 87 ("[T] he solidarity of an ideal community of communication, which follows the tightly interwoven basic norms of equality and equal responsibility for the raising and solving of problems in the mutual recognition of the 
Developing Gadamer's work, Habermas believes that "Communicative freedom exists only between actors who, adopting a performative attitude, want to reach an understanding with one another about something and expect one another to take positions on reciprocally raised validity claims." 100 Given the indifference of the epithet hurler, however, to reaching "an understanding," in any relevant, serious sense, there is no more reason for Habermas than for Gadamer to support the idea of including typical epithet speech within the purpose-based compass of freedom of speech. As with Gadamer, this conclusion would be founded on reasons separate from any prior disagreement with, or distaste for, the content of the epithet.

Habermas recognizes that some forms of verbal behavior can actually amount to the exercise of social power, ${ }^{101}$ if not to sheer domination, ${ }^{102}$ and to a reflection of social violence. ${ }^{103}$ Surely much epithet speech can be thought of precisely in such terms. But Habermas's approach to speech is much broader and offers broader insight. As it turns out, his evolving approach to communicative action may help us more deeply or appropriately assess hate speech, even if some of the elements of Habermas's approach itself may be questioned.

Habermas follows J.L. Austin ${ }^{104}$ in noticing that in some if not all cases, the speaker performs an action in speaking. ${ }^{105}$ While

partners in discourse, has to be presupposed, and even be counterfactually anticipated, as every serious act of argumentation demonstrates.").

100. HABERMAS, supra note 5, at 119.

101. See JÜRgen Habermas, ON THE LOGIC OF THE SOCIAL SCIENCES 172 (Shierry Weber Nicholsen \& Jerry A. Stark trans., MIT Press 1988) (1970); see also THOMAS MCCARTHY, THE CRITICAL THEORY OF JÜRGEN HABERMAS 183 (1981) ("Language is also a medium of domination and social power.").

102. See HABERMAS, supra note 101 , at 172 ; see also RICOEUR, supra note 90 , at $85-86$ (referring to the Habermasian conception of "violence in discourse").

103. See JÜRGEN HABERMAS, KNOWLEdGE AND HUMAN INTERESTS 314-15 (Jeremy J. Shapiro trans., Beacon Press 1971) (1968) ("Only when philosophy discovers in the dialectical course of history the traces of violence that deform repeated attempts at dialogue and recurrently close off the path to unconstrained communication does it further ... mankind's evolution toward autonomy and responsibility.").

104. See supra notes 7,46 .

105. See 1 HABERMAS, supra note 6 , at $288-90$ (following Austin's distinctions among locutionary, illocutionary, and perlocutionary acts); 2 JÜRGEN HABERMAS, THE THEORY OF COMMUNICATIVE ACTION 62 (Thomas McCarthy trans., 1985) (1985) ("With performative sentences the speaker carries out an action in saying something.") (emphasis omitted). We have seen that it will often be difficult to classify a particular effect of epithet speech as either illocutionary or perlocutionary. See supra notes 49-50 and accompanying text. Habermas argues that the strategic pursuit of perlocutionary aims requires deception, or attempted 
"[r]eaching understanding is the inherent telos of human speech,"106 not all literal speech will remotely fit, or even seek to fit, this pattern. ${ }^{107}$ Much epithet speech, presumably, will not be aimed at reaching understanding in a Habermasian sense.

Habermas himself focuses on convicting some speakers of a performative contradiction. ${ }^{108}$ To speak is, according to Habermas, to impliedly issue a series of warranties, ${ }^{109}$ given what is inescapably presupposed by ordinary speech. ${ }^{110}$ The epithet hurler may or may not be violating any of those implied warranties, thereby ensnaring

deception, regarding the fact that one is acting strategically. See 1 HABERMAS, supra note 6, at 294. This specification does not seem to bear upon the typical case of epithet speech.

106. 1 HABERMAS, supra note 6, at 287.

107. See, e.g., id. at 285-86 (distinguishing "strategic" from "communicative" action). We should note that typical epithet speech is really neither "communicative" nor "strategic." It is not communicative insofar as it fails to aim at reaching an unimposed understanding in Habermas's sense, nor is it strategic insofar as epithet speech fails to follow rules of rational choice aimed at "influencing the decisions of a rational opponent." See id. at 285-87. For further discussion, see J. Donald Moon, Practical Discourse and Communicative Ethics, in THE CAMBridge Companion to Habermas 143, 146 (Stephen K. White ed., 1995).

108. See, e.g., Jürgen Habermas, MORAL CONSCIOUSNess AND COMMUNICATIVE ACTION 80 (Christian Lenhardt \& Shierry Weber Nicholsen trans., 1990) [hereinafter HABERMAS, MORAL CONSCIOUSNESS]. The germ of the idea, intuitively, asks us to think about someone who orally proclaims their inability to speak, or their unconsciousness, or their severe laryngitis, or their complete ignorance of language. See also Mark Gould, Law and Philosophy: Some Consequences for the Law Deriving from the Sociological Reconstruction of Philosophical Theory, 17 CARDOzo L. REV. 1239 (1996); Jürgen Habermas, Reply to Symposium Participants, 17 Cardozo L. Rev. 1477 (1996); Francis J. Mootz III, The Paranoid Style in Contemporary Legal Scholarship, 31 Hous. L. REV. 873, 886 n.43 (1994); Pierre Schlag, Law As the Continuation of God by Other Means, 85 CAL. L. REV. 427, 435 (1997) (noting that to deny the "I" is "to itself reassert the existence of the 'I"').

109. Some years ago, for example, Habermas indicated that the apparent consensus-seeking language game participant impliedly underwrites "the comprehensibility of the utterance, the truth of its propositional component, the correctness and appropriateness of its performatory component, and the authenticity of the speaking subject." HABERMAS, supra note 98, at 18; see also FRED R. DAllmaYR, CRITICAL ENCOUNTERS 80 (1987). More recently, Habermas has held as among the presuppositions of argumentation that "[e]very subject with the competence to speak and act is allowed to take part in a discourse" and that "[e]veryone is allowed to express his attitudes, desires, and needs." HABERMAS, MORAL CONSCIOUSNESS, supra note 108 , at 89 . One could argue, certainly, that virulent racist speech or the use of racial epithets tends to suppress or silence the expressive speech of its targets. See, e.g., MATSUDA ET AL., supra note 1; Craig B. Bleifer, Looking at Pornography Through Habermasian Lenses: Affirmative Action for Speech, 22 N.Y.U. REV. L. \& SoC. CHANGE 153, 185 (1996) ("Deafening speech prevents someone else from speaking or from being heard.").

110. See, e.g., HABERMAS, MORAL CONSCIOUSNESS, supra note 108, at 95 . Habermas believes that such presuppositions, perhaps translatable into norms, are not merely arbitrary, conventional, or perpetually avoidable. There is simply no realistic alternative to them if a genuine argumentative conversation is to be undertaken and pursued. See id. at 95, 102. We should note that Habermas seeks to distinguish, successfully or not, between ordinary communicative action and what he terms 'discourse,' which features less thoroughgoing initial agreement. See Solum, supra note 77, at 115 . Even if this distinction is tenable and for some purposes important, it does not seem crucial for the points we make herein. 
himself or herself in some sort of performative contradiction. ${ }^{111}$ But whether the epithet hurler actually engages in a performative contradiction is really not crucial for our purposes.

Instead, we might simply ask whether the epithet hurler intends the sort of speech activity that is logically included under the Free Speech Clause, given the latter's assumed purposes, again quite apart from any disagreement with the content of the speaker's message. At this point, we can call upon Habermas's discussion of ideal or undistorted communication for illuminating contrast. The point is, of course, not that free speech is worth protecting only in unrealized, ideal circumstances. Certainly, we want to protect the speech of more than just our most enlightened or mature citizens. Rather, Habermas's description of an unrealized communicative ideal may again allow us to think more clearly and impartially about what sorts of speech fall within the proper scope of the Free Speech Clause. ${ }^{112}$

Habermas refers to "an ideal communication community encompassing all subjects capable of speech and action."113 Importantly for our purposes, "[e]very justified truth claim ... must ultimately be able to command the rationally motivated agreement of the community of interpreters as a whole. Here an appeal to some particular community of interpreters will not suffice." 114 It seems clear enough that typical instances of epithet speech will be far removed from such a paradigm. Yet, this is not a matter of our assessing the baseness, truth, or falsity, in any sense, of any message logically implied or even vaguely suggested by epithet speech. Our point is not that claims of group superiority and inferiority, for example, will likely not prove convincing on the merits to an entire community, including those disparaged by such a claim. It would

111. See supra notes $108-10$ and accompanying text. For further discussion of the ideal speech situation and its presuppositions, see RICHARD J. BERNSTEIN, THE RESTRUCTURING OF SOCIAL AND POLITICAL THEORY 212-23 (1976) ("All potential or actual speech presupposes and anticipates ideal speech, which in turn requires the material conditions ... in which such speech can be concretely realized."); WILlIAM OUTHWAITE, HABERMAS: A CRITICAL INTRODUCTION 40 (1994); David Couzens Hoy, Interpreting the Law: Hermeneutical and Poststructuralist Perspectives, 58 S. CAL. L. REV. 135, 160-62 (1985); Mootz, supra note 13, at 575-76.

112. For such purposes, we may want to bear in mind one or more of the various possible purposes or values that might plausibly be thought to underlie the value of free speech in the first place. See supra notes $94-97$ and accompanying text. For a strong and especially interesting broader claim, see Solum, supra note 77, at 106 ("[F]reedom of speech is best understood as an attempt to institutionalize the essential conditions of the ideal speech situation.").

113. HABERMAS, supra note 9 , at 50.

114. Id. at 53 ; see also id. at 52 ("Valid statements must admit of justification by appeal to reasons that could convince anyone irrespective of time or place."). 
defeat the functional logic of free speech to protect or not protect forms of speech based on how plausible or logically convincing anyone finds that speech. ${ }^{115}$

The point instead goes to the ambitions or intent underlying typical epithet speech. Any neutral and reasonable observer would conclude that such epithets ordinarily are not even loosely, indirectly intended to ever inspire broad, let alone universal, public conviction. It is not as though epithet hurling is intended even as a mere contribution to public debate, with the realistic appreciation that the targets of the invective are unlikely to ratify their own denigration. Epithet hurling is typically not intended to persuade some uncommitted middle ground of public opinion or even to reinforce the views of confirmed racists in the audience. It is typically not intended to persuade anyone, including the speaker, of anything, to prepare the way for such persuasion, or to legitimize and reinforce any set of social beliefs. ${ }^{116}$ Epithets do not, in any sense, invite discourse. ${ }^{117}$

This claim certainly does not deny that even the bare epithet has a certain locutionary or other sort of content, if only in the form of an implied evocation of some sort of racial invidiousness, with all its possible cultural resonances. ${ }^{118}$ But the point of the speech, we may assume, is something like to degrade, to inflict pain and anxiety, and to indirectly exalt the speaker's group by comparison. The intent is thus akin to punching or kicking for group-based reasons. ${ }^{119}$ Doubtless a literal punch or kick can effectively communicate a clear, specific message. Sometimes, a punch carries an unmistakable message. But we rightly do not think of, say, a race-based beating as speech or expression for preliminary free speech purposes, whether we regulate such "expression" in some fashion or not.120 Habermas can offer a deeper and more detailed foundation for our thinking in such fashion.

There is, certainly, nothing question-begging or unfair about noticing that not all forms of literal speech have identical aspirations

115. See supra note 96 and accompanying text.

116. See supra notes $26,33-34$ and accompanying text.

117. See supra note 34 and accompanying text.

118. See supra note 30 and accompanying text.

119. See supra notes $43-45$ and accompanying text.

120. It is useful to bear in mind the distinction between activity that falls outside the logical scope of speech itself, for free speech purposes, and speech that falls within that scope, but that we understandably wish to regulate for some reason. See FrEDERICK SCHAUER, FREE SPEECH: A PHILOSOPHICAL ENQUIRY 89-92 (1982). 
or intended effects. Habermas rightly points out that "in the symmetry conditions and reciprocity expectations of everyday speech oriented to reaching understanding, there already exist ... the basic notions of equal treatment and general welfare on which all morality turns." 121 Similarly, there is no reason to believe that whatever reasons we may have for protecting freedom of speech must themselves be, in all respects, politically neutral. Nor would this sort of neutrality be desirable.

Moral thinking, in turn, requires that "[e]ach of us must be able to place himself in the situation of all those who would be affected by the performance of a problematic action or the adoption of a questionable norm." 122 Some epithet speakers may reply that in some proper, if rather starkly limited sense, they favor equal treatment on the basis of race. Their epithets may still be appropriately legally judged. And if some epithet speakers do not propose to respect any form of equal treatment, it is hardly unfair to notice this fact, as long as we draw only the proper inferences from such an admission. ${ }^{123}$

Again, this approach does not promote the notion that a speaker who rejects some conception of equality, or of how moral principles must be universalized, should be prohibited from speaking. Certainly some such speakers will in fact still be promoting our reasons for protecting free speech, as in the case of current thoughtful debates over the moral status or equality of various forms of animal life. ${ }^{124}$ But equally certainly, not all verbal racial abuse can reasonably be

121. HABERMAS, supra note 9, at 50. A bit more elaborately, Habermas argues that "[g]iven the communicative presuppositions of an inclusive and noncoercive discourse among free and equal partners, the principle of universalization requires each participant to project himself into the perspectives of all others." Id. at 52. For discussion of the role of universalization in morality, see R.M. HARE, MORAL THINKING: ITS LEVELS, METHOD, AND POINT 20-24 (1981).

122. HABERMAS, supra note 9 , at 49. This is of course not to claim that every speaker who does not aspire to some sort of impartial, universalist morality falls outside the scope of the purposes and coverage of the Free Speech Clause. For further discussion, see HOY \& MCCARTHY, supra note 77, at 55 ("[A]s Habermas conceives of it, practical discourse demands of participants that they take into consideration the needs and interests of all who will be affected by the outcome of their deliberations.").

123. At the level of broad principle, see Otfried Höffe, Kantian Skepticism Toward Transcendental Ethics of Communication, in THE COMMUNICATIVE ETHICS CONTROVERSY, supra note 99, at 193, 218 ("[I]t is the task of the legal order to make possible institutionally discursive will-formation in the framework of the communicative process."). Habermas thus recognizes a moral requirement in the "transformation of the material conditions that block and distort communication." BERNSTEIN, supra note 85, at 190.

124. See, e.g., Peter Singer, Practical ETHICS 110-34 (2d ed. 1993). 
said to cohere as well with our reasons for protecting free speech in the first place. ${ }^{125}$

\section{CONCLUSION}

We have herein focused mainly on some congruences between Gadamer and Habermas, as opposed to their perhaps occasionally overdrawn or overemphasized points of contention. Neither Gadamer nor Habermas offers a template for resolving constitutional free speech cases in general, or any sort of hate speech case in particular. What they jointly offer of primary importance for us, though, is a deep, thorough, and sensitive account of social conversation that suggests why restricting hate speech does not amount simply to censoring an unattractive view of the world. They help us, instead, to more incisively appreciate how all forms of literal speech are not created equal, and why we can make reasonable progress in sorting out literal speech that generally tends to promote the values underlying freedom of speech from literal speech that does not, without betraying those values in the process.

125. See supra notes $94-97$ and accompanying text. 